\title{
WestVirginiaUniversity
}

THE RESEARCH REPOSITORY @ WVU

West Virginia Agricultural and Forestry Experiment

Davis College of Agriculture, Natural Resources

Station Bulletins

And Design

$1-1-1958$

\section{Marketing forest products in West Virginia}

Wallance W. Christensen

Allen W. Goodspeed

Follow this and additional works at: https://researchrepository.wvu.edu/

wv_agricultural_and_forestry_experiment_station_bulletins

\section{Digital Commons Citation}

Christensen, Wallance W. and Goodspeed, Allen W., "Marketing forest products in West Virginia" (1958). West Virginia Agricultural and Forestry Experiment Station Bulletins. 421.

https://researchrepository.wvu.edu/wv_agricultural_and_forestry_experiment_station_bulletins/400

This Bulletin is brought to you for free and open access by the Davis College of Agriculture, Natural Resources And Design at The Research Repository @ WVU. It has been accepted for inclusion in West Virginia Agricultural and Forestry Experiment Station Bulletins by an authorized administrator of

The Research Repository@WVU. For more information, please contact ian.harmon@mail.wvu.edu. 
Marketing Forest Products in West Virginia

tex

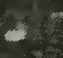

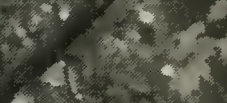

7 in s. $b^{2} x^{2}+x^{2}$

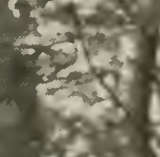
$2+1$.

. 4306

S... $t^{2}=$

fritis

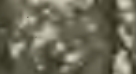

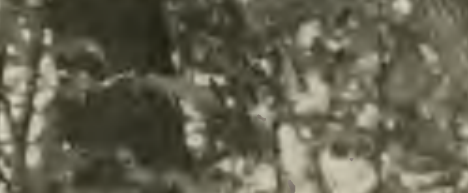

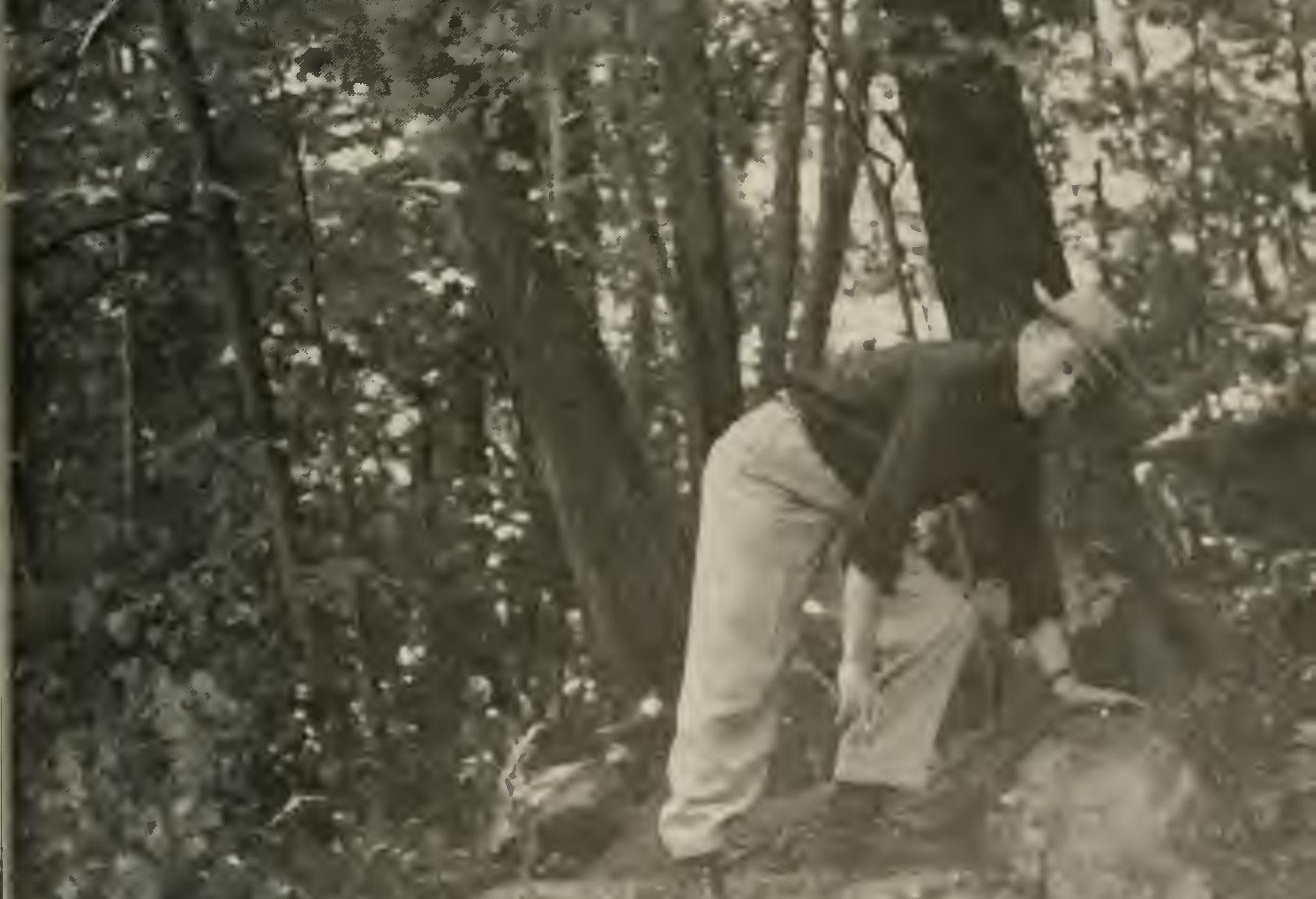

\section{BUIAETIN 421} JUNE 1958 


\section{AUTHORS}

Authors of Marketing Forest Products in IVest Virginia are Wallace W. Christensen, Assistant Professor of Forest Management and Assistant Forester in the Agricultural Experiment Station, and Allen W. Goodspeed, Professor of Forest Management, and Forester in the Agricultural Experiment Station.

West Virginia University

Agricultural Experiment Station

Coillege of Acriculture, Forestry, and Home Economics

A. H. Vanlandingham, Acting Director

MORGANTOWN 


\section{Contents}

INTRODUC:TION

I.I6;:

RESEARCH PROCEDURE

GENERAL DESCRIPTION OF WOOIDLANI) OWNERSHIP . \&

SALES OF FARM WOOIMLAND PROIUUCTS ........... II

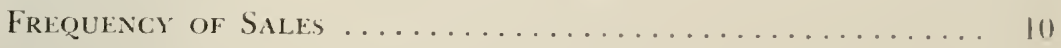

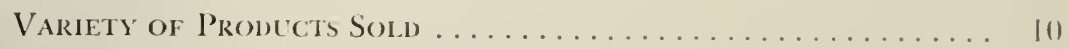

ReASONS FOR SALE ....................... II

VOLUME OF PRODLCTS MARKETED ............ I!

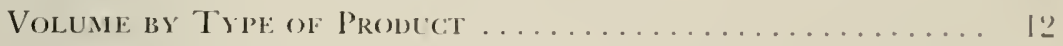

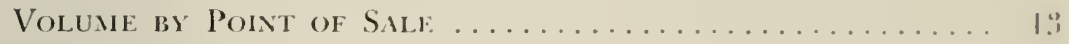

Volune by SPecies ...........................

VALUE OF PRODUCTS MARKETED .............. II

Value by Trie of Prodeci .................. 15

VALUE BY PONT OF SALE ................... 17

VALUE Bi SPllcies ..........................

MARKETING PRACTICES . . . . . . . .

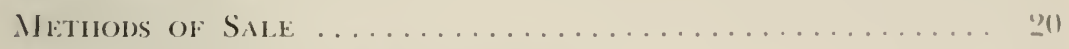

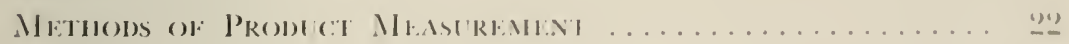

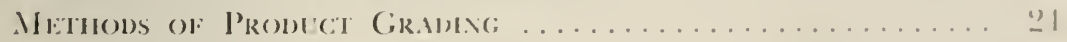

FAMILIARITY OF SELALRS WITH TIMBER PRODULCIS

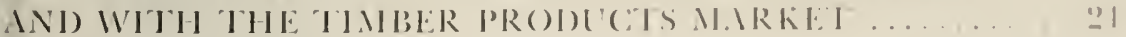

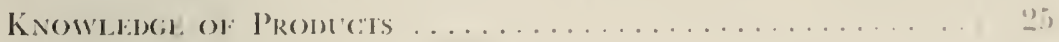

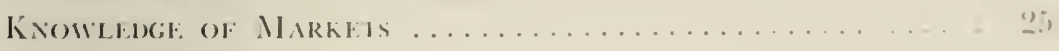

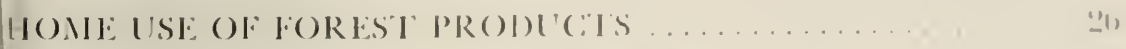

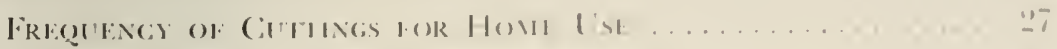

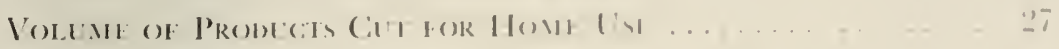

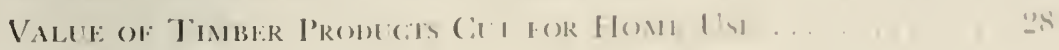

ONCLUSION .................. 


\section{List of Illustrations}

FIGI'RE:

I Distribution of sampling areas ..................

2 Forest cover composition and stand-size classes for sample units (area percentage distribution) $\ldots \ldots \ldots \ldots \ldots \ldots \ldots \ldots \ldots \ldots \ldots$

3 Percentage distribution of products marketed ........... 12

4 Percentage distribution of volume marketed by point of sale ... 14

5 Percentage distribution of sales by method of price determination 20

6 Percentage distribution of sales by person measuring . . . . . . 23

\section{List of Tables}

TABLE

I Number of units in sample, average unic area, and average woodland area by woodland area size class ................

2 Number of units selling by sales frequency class and woodland

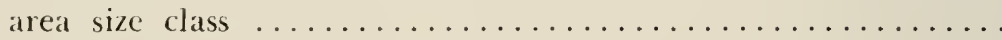

y Total ownership units and number selling during 1947-5 l period

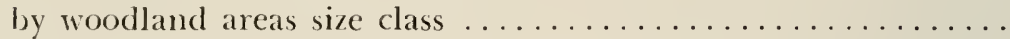

4 Number of units selling by number of products and woodland

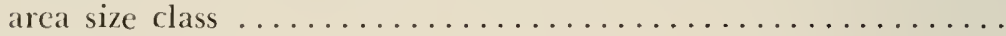

5 Comparison of sales volume distribution and value per unit of sales volume-by product class

6 Cash return per 100 cubic feet of volume marketed-by product

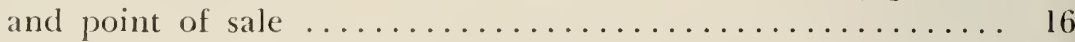

7 Species marketed-by value and major product outlet ....... 18

8 Basis of payment ......................... 1

9 Reasons for buyer selection ................... 22

1) Percentage distribution of volume marketed-by type of measure-

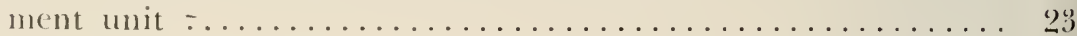

Il Distribution of sales-by presale knowledge of markets . . . . . . .

I2 1)istribution of sales-by presale knowleclge of available marketing

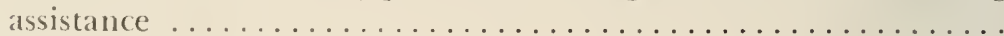

13 Number of cuttings for home use by reason for cutting and woodland area size class .......................

1.1 Average annual volume of products cut for home use-by product and woodland area size class ....................

15 Average ammal value of products cut lor home use-by product

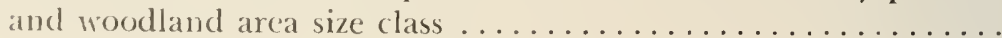




\section{Marketing Forest Products In West Virginia}

\section{Introduction}

WALLACE W. CHRISTENSEN and ALLEN W. GOODSPEED

W EST VIRGINIA'S forest resource has, for many years, comtributed significantly to the raw material requirenents of hadwood-using industries in the Nation. Although the state ranks only foth in the Nation in terms of land area, it has been one of the six leading producers of hardwood lumber throughout the present century and, currently, stands 7 th in national rank with respect to its volume of standing landwood sawtimber. In addition to their commercial contribution, the forests. which occupy 64 per cent of the State's land area, also provide services in the form of watershed influences, willlife habitat, and recreational use. Since forests are of considerable importance to the people ol Went Virginia, it follows that they must eventually come moler a form of management which will insure sustained production of the goods and services involved.

Of the many lacets involved in the problem of coliblishing and maintaining desirable forest managenent practices, manketing plats al major role. As in most industries, forest goods are produced in almuctr to consumer demand. Hence the management of foreses must necensalil? be geared to the markets for forest products, since thene mankets comstitute the reflection of user demand. This close relationship) beencens management and maketing means also that the eflicience of the man. keting process will affect, to some degree, the intensit! ol lonest matnafige ment. If maximum eflicicncy may be delined as the optimmun ane of

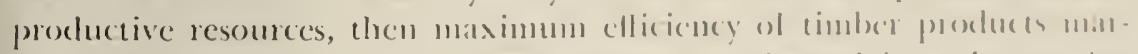

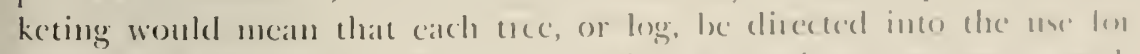

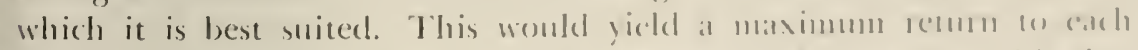

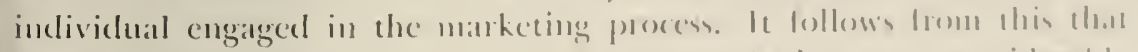

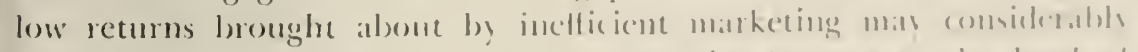

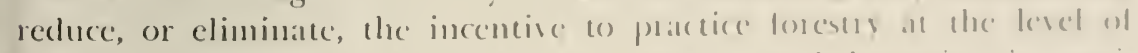

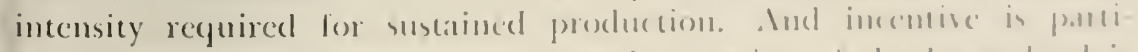

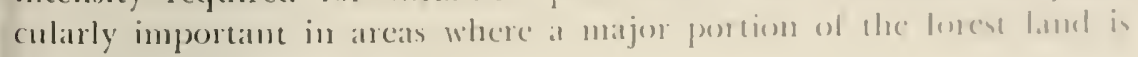
held by surall private owners. 
In West Virginia, 90 per cent of the commercial forest land is held b) 193,571 private owners. Nincty-nine per cent of these are small owners-with 500 acres or less of woodland-who, in the aggregate control two-thirds of the privately-owned forest acreage. Nlthough the timber marketing problems of small woodland owners have been well described in Duerr's study of the Appalachian region, ${ }^{1}$ there has been 110 specific state-wide study on the subject in West Virginia. The object of the present study is to fill this gap by investigating the marketing customs and practices of those private owners in the State who hold between 10 and 500 acres of woodland. Implicit in the study is the aim of ascertaining problem areas in the marketing process at the owner level and, by so doing, to point out the direction lor lunther research.

\section{Research Procedure}

This study was undertaken as a contributory project to the Northeast Regional Marketing Project NEM-6, "Marketing Forest Products." The analysis and conclusions in this report, however, relate only to West Virginia.

A statistical design, of the area sampling type, was provided by the Agricultural Marketing Service, United States Department of Agriculture, for each state in the regional survey and, for West Virginia, it involved a distribution of 145 sampling areas throughout 26 of the 55 countics in the State (Figure 1). Interviews were conducted with all forest land owners in these sampling areas. A total of 630 complete schedules were secured for ownerships with woodland areas between 10 and 500 acies.

Fanm ownership units accounted for 627 of the 630 sample units. Since the three nonfarm units represented less than 1 per cent of the total rooxlland acreage in the sample, they were exchuded from the analysis. Accordingly, this report considers the marketing customs and practices of lam woodland owners only.

For each ownership nut, data were obtained on woodland area and composition, product use, and sales of products for the five-year period of 19.17 through 1951. The lorest products sales were investigated in considerable detail with information being secured on volume of products sold by type of product, species cut, unit of measurement, point of sale, and prices received; reasons for sale of woodland products: patterns of sale, inchuding owner's fandiarity with the market, initiators of sales, and methods of price determination; and the selection, grading, and measurement of products.

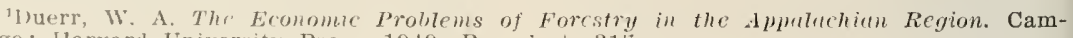
bridge: Ilarvard Lniversity Press, 1949. Pp. xi $+31 \%$ 


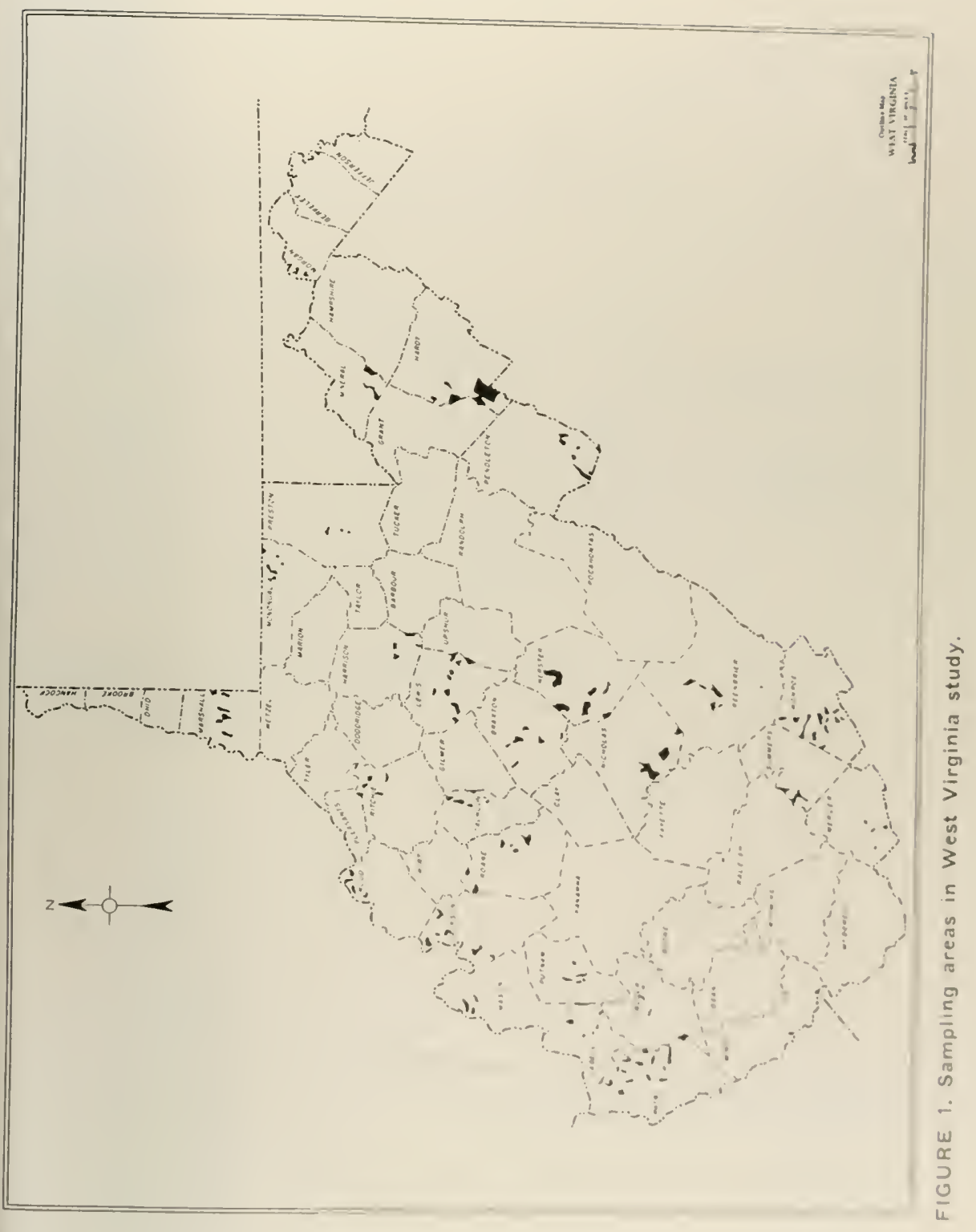




\section{General Description of Woodland Ownership}

A total farm arca of 83,279 acres was reported for the 627 sample units of the study. Forest land occupies 42.6 per cent of this area and, as would be expected in the Appalachian hardwood region, the forest land is made up predominantly of the hardwood cover types. Figure 2 indicates that almost 98 per cent of the total forest acreage is composed of the hardwood and mixed-wood types, with the hardwoods accomting for 85.2 per cent of the total. Within each of the three lorest cover types an ahmost equal area distribution, according to stand size class, is shown. ${ }^{2}$

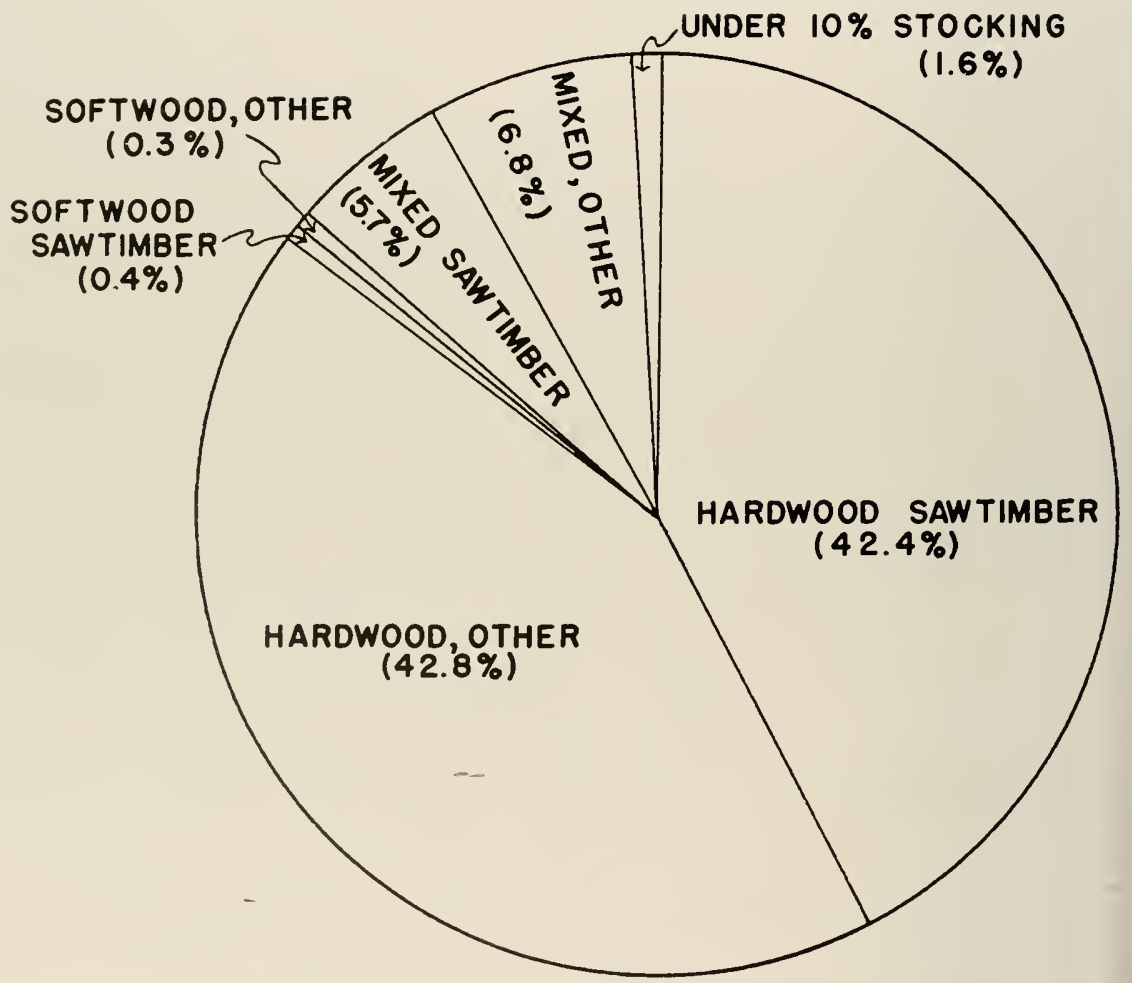

FIGURE 2. Forest cover composition and stand-size classes for sample units (area percentage distribution).

Small woodlands, ranging from 10 to 150 acres, make up the major portion of the lorest area. The data presented in Table 1 indicate that

"sumfinber stmol: a forest stand containing 1,500 board feet or more per acre of trees of minimum diameter specifications. For hardwood species the minimum diameter at breast hright was 11 inches, for softwood species a minimum diameter of 9 inches was required.

other stumls: a forest stand not qualifying as sawtimber. 


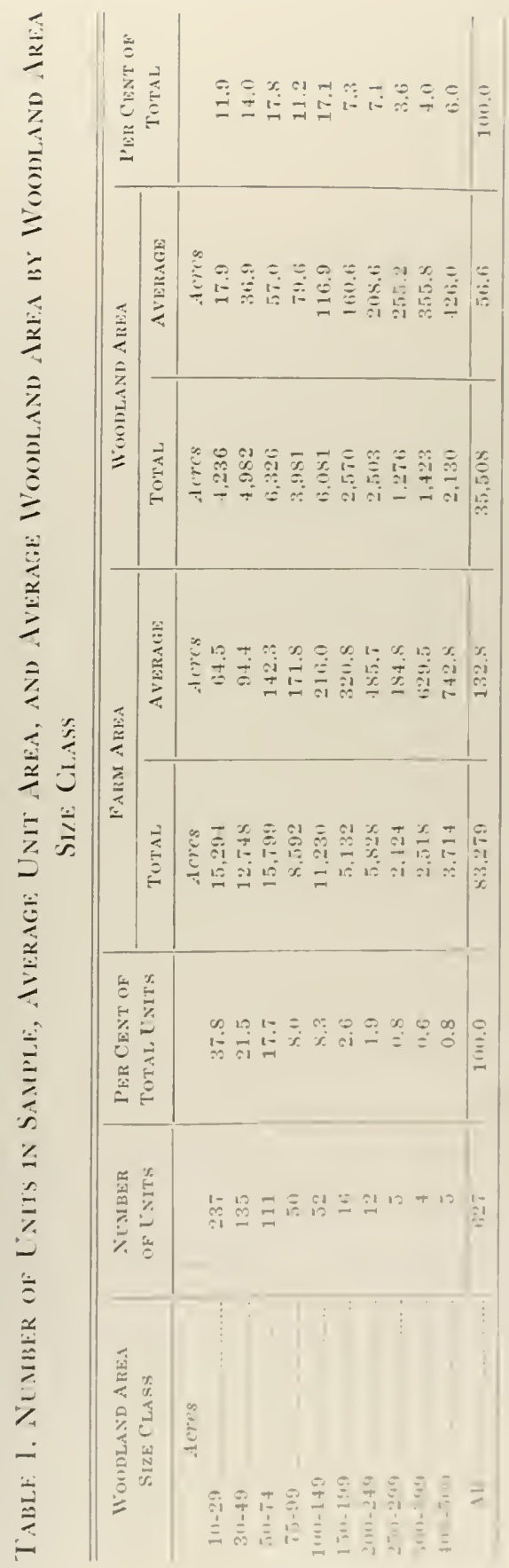


72 per cent of the total wooded area of the sample is found in these small woodland area size classes. Funther, these small classes include 93 per cent of the 627 owner units in the sample. In addition to holding the largest portion of the woodland area, the small woodland owners also control a major portion of the sawtinber stands in the sample. Seventyfrve per cent of the sawtimber acreage is in units in the woodland area size classes between 10 and 150 acres; almost 50 per cent of the total is found in roodlands of 75 acres or less.

In general, then, nearly one-half of the totai area of the sample is covered by forests that (a) are predominantly of the hardwood cover types, (b) contain sawtiuber stands on about 50 per cent of their area, and, (c) are comprised mainly of many small holdings.

\section{Sales of Farm Woodland Products}

\section{FREQUENGY OF SALES}

Twenty-six per cent of the 627 respondents reported sales of forest products for the $1947-195 \mathrm{I}$ period. The data in Table 2 reveal that more than 75 per cent of these sellers made but one sale cluning the five-year period; only 6 per cent of all sellers made more than two sales.

Table 2. Number of Sample Units Selling in IVest Virginia, 1947-51, by Sallas Frequency Class and Woomand Area Size Class

\begin{tabular}{|c|c|c|c|c|c|}
\hline \multirow{2}{*}{$\begin{array}{c}\text { Woodland Area } \\
\text { Size Class } \\
\text { (ACres) }\end{array}$} & \multicolumn{3}{|c|}{ SALES FrequeNCy Class } & \multirow{2}{*}{$\begin{array}{c}\text { AlL } \\
\text { Classes }\end{array}$} & \multirow{2}{*}{$\begin{array}{c}\text { Per Cent } \\
\text { TOTAL }\end{array}$} \\
\hline & 1 & 2 & OVER 2 & & \\
\hline $10-49$ & 62 & 12 & 3 & 77 & 47.0 \\
\hline $50-99$ & 45 & 10 & 2 & 57 & 34.7 \\
\hline $100-199$ & 14 & 4 & 3 & 21 & 12.8 \\
\hline Over 200 & 7 & 0 & 2 & 9 & 5.5 \\
\hline All classes & 128 & 26 & 10 & 164 & 100.0 \\
\hline Per cent of total & 78.0 & 15.9 & 6.1 & 100.0 & \\
\hline
\end{tabular}

The data suggest also that the proportion of owners selling woodland products decreases with each increase in woodland area size class. But this might-be expected because the number of ownership units in calch class varies inversely with woodland area, that is, the largest number of ownership mits is found in the 10- to 49-acre class, the next largest number of moits in the 50- to 99-acre class, and so on. Actually, as is indicated in the last column of Table 3, no particular relationship exists between woodland area size class and number of units selling.

\section{VARIETY OF PRODUGTS SOLD}

A comparison of Table 4 with Table 2 shows that the findings on varicty of products sold are almost identical with those related to 
Table 3. Total Ownership ['Nits and Nimber Shling 1)uring 19:7-51 Period by Woudland Area Size Class, West V'irginia

\begin{tabular}{|c|c|c|c|}
\hline $\begin{array}{c}\text { WoOdLAND AREA } \\
\text { Size Class } \\
\text { (ACRES) }\end{array}$ & $\begin{array}{c}\text { TOTAL OWNERSHIR } \\
\text { UNITS IN CLASS }\end{array}$ & $\begin{array}{c}\text { NEMBER OF } \\
\text { UNITS SELLING }\end{array}$ & $\begin{array}{l}\text { NU MBFIR OF UNITS } \\
\text { SELLING AS A PER } \\
\text { CENT OF TOTAL } \\
\text { LNITS IN CLASS }\end{array}$ \\
\hline $10-49$ & 372 & 77 & 20.7 \\
\hline $50-99$ & 161 & 57 & 35.4 \\
\hline 100-199 & 68 & 21 & $3 \cap .9$ \\
\hline Over $200 \ldots . . .$. & 26 & : & 346 \\
\hline Total ....... & 627 & 164 & 26.2 \\
\hline
\end{tabular}

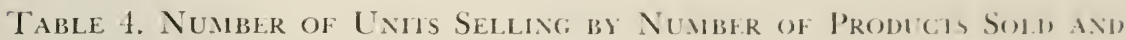
WoOdlaye Area Size Cilass, 1947-51, West Vikgivia

\begin{tabular}{|c|c|c|c|c|}
\hline \multirow{2}{*}{$\begin{array}{c}\text { Woodlasd AREa } \\
\text { Size Class } \\
\text { (ACREs) }\end{array}$} & \multicolumn{3}{|c|}{ Nituber of Pronects Suld } & \multirow{2}{*}{ ALI } \\
\hline & 1 & 2 & OVER 2 & \\
\hline $10-49$ & 63 & 12 & 2 & 77 \\
\hline 50-99 & 42 & 12 & 3 & 57 \\
\hline $100-199 \ldots$ & 14 & 5 & 2 & 21 \\
\hline Over 200 & 6 & 1 & 2 & 9 \\
\hline All classes & 125 & 30 & 9 & $1+; 1$ \\
\hline Per cent of total .... & 76.2 & 18.3 & 5.5 & $1018 . n$ \\
\hline
\end{tabular}

frequency of sales. Of the $16+$ setlers, 78 per rent made one sale anly and 76.2 per cent reported sale of one product only. For multiple siles and products, 22 per cent of the sellers reported making two m more siles as compared to 23.8 per ent who sold two or more products.

As might be expected, the proportion of owners selling mote that one product rises with increases in woodland ancal for example, siles involving more than one product were made hy 18 pere cims of alic

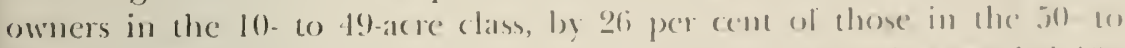

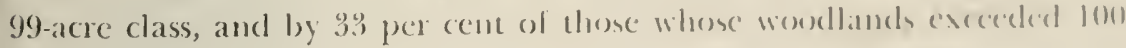
acres in size.

REASONS FOR SAIA

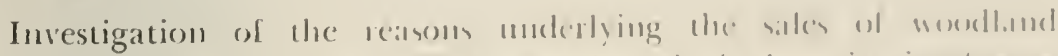

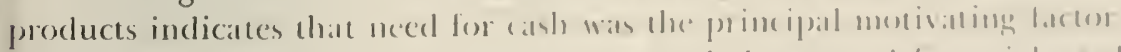

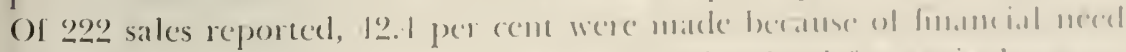

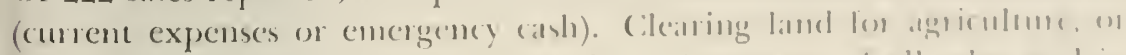

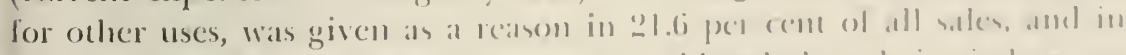
14.4 per cent of the sales the owners combideded that theil timber w.a

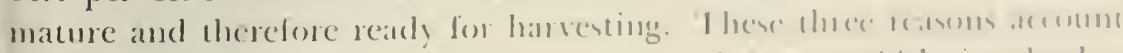

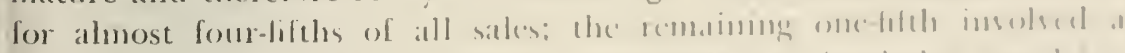

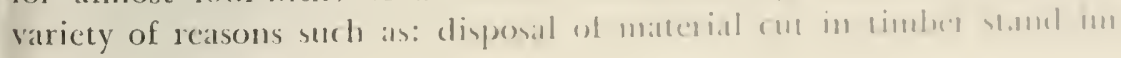


provement, budgeted cut in woodland managencnt plan, salvage of timber damaged by various causes, liquidation of capital gain, kecping labor and equipment employed during slack periods, and high product prices currently olfered.

The findings relative to sales of farm woodland products thus produce a general picture in which the majority of sales, motivated largely by owner's needs for money or for more open land, were made by small woodland owners, most of whom market one type of product in any given transaction.

\section{Volume of Products Marketed}

In developing a field schedule for use in the survey, 18 different product categories were included because of the known diversity in the timber products output of the Northeastern States. However, only 10 of these product classes were encountered in the investigation. The determination of volumes for these 10 products involved a variety in types of measurement units. Therefore, in order to make relative volume comparisons of the various products marketed, the volumes of the 10 classes were converted into culjic-foot equivalents. This conversion further reduced the number of product categories because of a grouping of some of the products whose individual total volumes were of negligible inportance.

\section{VOLUME BY TYPE OF PRODUCT}

For the five-year period investigated, 634,456 cubic fect of woodland products were marketed by the 164 sellers in the sample area. Sawlogs were the most important product, representing more than onehalf of the total volume of all timber products sold (Figure 3). Next

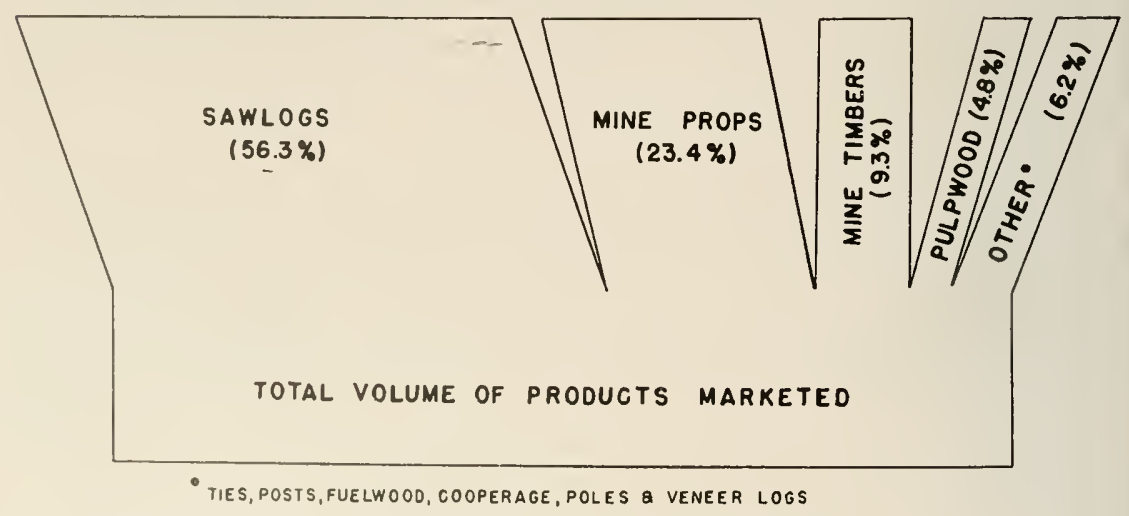

FIGURE 3. Percentage distribution of products marketed. 
in importance, as might be experted in a major coal-producing statle, were mine props and mine timbers. They accounted for approximately one-third of the volume of all sales. Together, these products commprised nine-tenths of the total sales volume.

The low volume of pulpriood can readily be explainced by the lack of primary pulp aud paper mills in W'est Virginia. Four mills are located just outside the State, but their pulpwood procurencut areas extend only a short distance into West Virginia and thus create a fringe market area along the State's borders only. Accordingly, the major per. centage of the farm woodlands are not located in pulpsheds, and the products sold therefore flow predominanty toward those wool-using and mining industries lying principally within the Statc.

\section{VOLUME BY POINT OF SALE}

The principal points of sale, on a rolume sold basis, were on the stump and at roadside. Figure f shows that more than onc-hall of the total volume was sold as stumpage and slightly over onc-foumb at roat. side. The combined volume at these wo points of sale accomts for 85.1 per cent of the total volume marketed.

Considering point of sale relative to type of probluct, 83 per cent of the sawlog volume and 98 per ecut of the minc timber volume was sold on the stump, 85 per cent of the mine prop volume was sold at roadside, and 71 per cent of the pulpwood volume was sold att the mill or plant.

\section{VOLUME BY SPECIES}

Of 12 species and 5 specics-groups cucountered in this study, ? hardwood species gromps, nothern hardwoods and mixed hardwouds. accomnted for 85 per cent of the total volume of all speries malleted. Beech, birch, and maple were common comstituconts of the monthern hardwood gromp, while the mixed hardwool gromp) romaindel lew ol the foregoing species and also excluded pure oak stands. Ho predenni nance of the volume in these two groups resuled from the inalilits os

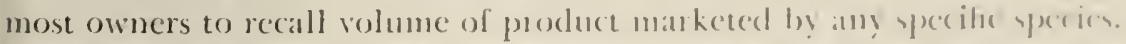

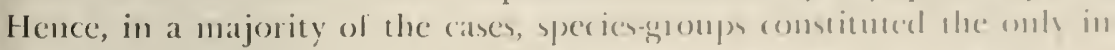

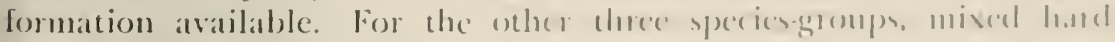

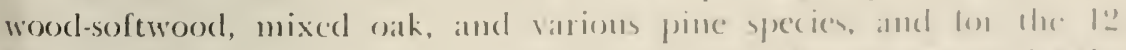

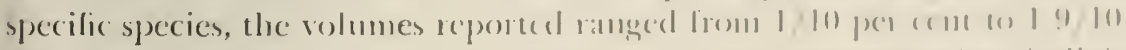

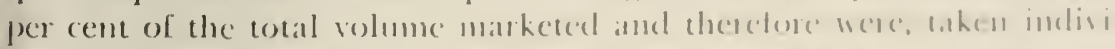
dually, of relatively mines if mot negligible impontance.

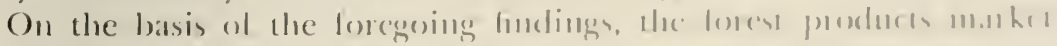

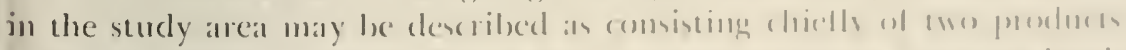

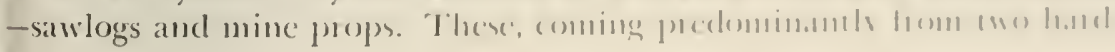




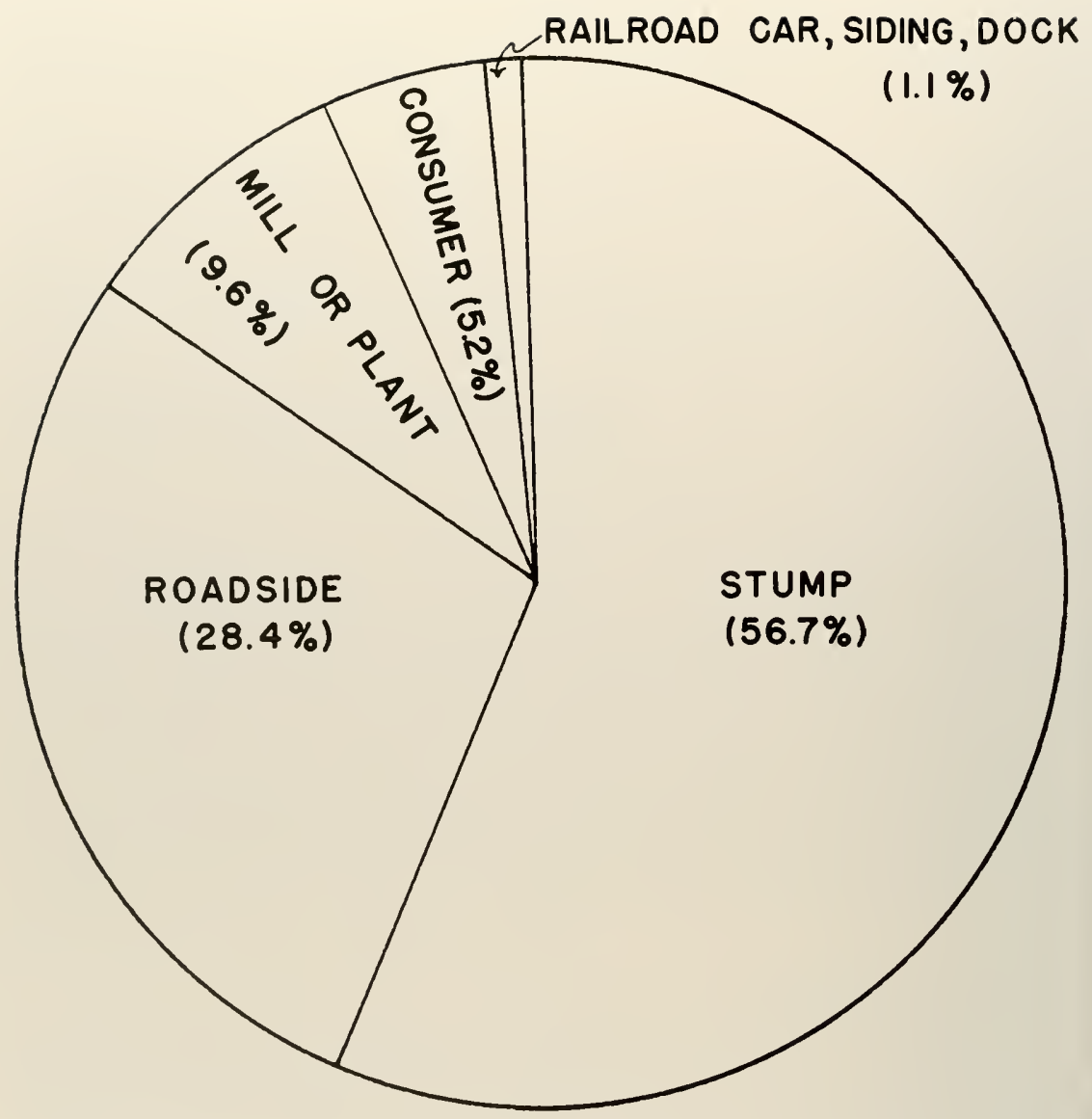

FIGURE 4. Percentage distribution of volume marketed by point of sale.

wood species-groups, are sold close to their point of origin, with stumpage sales accounting for most of the sawlog volume marketed and roadside sales representing the major portion of the mine prop volume sold.

\section{Value of Products Marketed}

Although 222 sales were reported by the 164 sellers intervicwed in this study, data were incomplete on 85 sales because sellers were unable (1) recall the sales information sought; volume of rood sold, type of product, and price received per unit of product. For the 137 sales on which data were obtained, a cash return of $\$ 59,235.56$ was reported. I his, since it covers a five-year period and involves 5,951 acres of forest land, represents a mean annual return of $\$ 1.99$ per acre from sale of lorest products. 
The above findings are based on two types of sale. Twenty-five Immp' sum sales, involving 1,344 acres of forest land, returned $511,075 .(11)$. 1\%. remaining $\$ 18,160.56$ represents the return from sales in which payment was made on a product measurement basis. Therefore, by wal of comparison, the mean anmual return from lump sum sales amounted to $\$ 1.65$ per acre in contrast to an average annual return of 52.09 per acre hom product measurement sales.

\section{VALUE BY TYPE OF PRODUCT}

An adequate analysis of value data on types of forest products requires the establishment of some mit, common to all types of products. by which value can be expressed. If this is not dome, product values must be expressed in aggregative terms, i.e., total rolmme sold multipliod by the price received per unit of that volume. Such values, however, preclude comparative atralyses because of variations in the rolume of sale and becanse of differences in the types of meanming mits cmplored for different type of products. Since the volumes of all products have been converted into cubic-foot equivalents, value mity be expressed in terms of dollars received per 100 cubic feet of wood sold. On this bisis a comparative analysis of product values is possible.

In general, considerable variation in value exists between the product classes encountered in the study. Is indicated in the linst column of Table 5, the values per 100 cubic feet of volume marketed rangeal from \$3.20 to \$101.13. This variation, lnowever, octurs in two patterns. First, the data show that product values fall into two major groupsa high-value group consisting of vencer logs, tight comperager. pusts, and ties, and a low-value group mate mp of the remaining poulurts. The

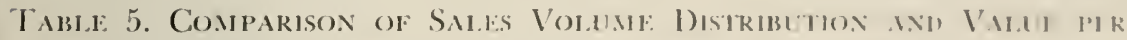

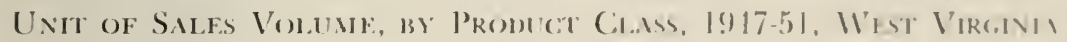

(bisIs:-112 SAIL)

\begin{tabular}{|c|c|c|}
\hline Pronfert & 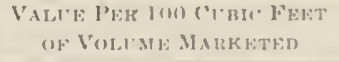 & 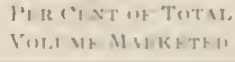 \\
\hline & lollurs & In ant \\
\hline Tight cooperage & $111 \cdot 1,13$ & 11.4 \\
\hline Posts ..................... & $13 i 3.4 \mathrm{~s}$ & 14 \\
\hline Veneer logs ... . & $\because 2.19$ & $11: 1$ \\
\hline Ties $\quad \ldots \ldots$ & $21: 1 ! 1$ & $1: 1$ \\
\hline 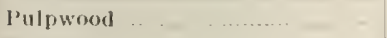 & $15 .: 11$ & 14 \\
\hline l'uelwool & S. III & $1:$ \\
\hline 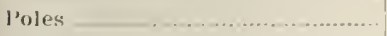 & $7.10^{\circ}$ & 1170 \\
\hline Silwlogs & 5.17 & An: $:$ : \\
\hline Hine props ....... & 4.85 & $\therefore .11$ \\
\hline Mlue ilmbers ............................. & 3.20 & is 3 \\
\hline Al1 & $7.5 !$ & $(131)$ \\
\hline
\end{tabular}

- Dala from one sale only. 
(lifference between these two groups is primarily due to the relationship) between product quality and price. The highest quality products usually receive the highest per-muit prices. Quality, in this case, refers either to the expected appearance of the processed wood, as in veneers, or to certain required physical and chemical properties of rood, as in cooperage, ties, and posts.

Second, a variation exists within each of the two value groups. This "within" variability arises, in part, from the fact that the value of each product is a weighted average and, as such, represents the interaction that occurs between price and the volume of product marketed by point of sale. For example, although the value per 100 cubic feet of sawlogs was slighily higher at each point of sale than the value received for pulpwood (see Table 6), the average all-points-of-sale value for pulpwood was three times as great as that for sawlogs. However, 83 per cent of the sawlog volume was marketed on the stump, whereas 71 per cent of the pulpwood volume was sold at the mill. Since the price per unit of product rose as the point of sale became further removed from the stump, the major portion of the pulpwood volume was accordingly marketed at a considerably higher price per 100 cubic feet than was the case for sawlogs, and the resulting weighted average value of pulpwood therefore exceeded that of sawlogs.

The relatively high value for posts in the high value group, and for fuelwood in the low-value group, is most likely caused by such factors as familiarity of sellers with product, with product measurement, and with the market price of the product. These particular influences will receive further consideration in subsequent sections of this bulletin.

Table 6. Cash Return per 100 Cubic Feet of Volume Marketei-by Proluct and Point of Sale, 1947-51, West Virginia

(BASIS:-112 SALES)

\begin{tabular}{|c|c|c|c|c|c|}
\hline FRODUCT & STUMPAGE & ROADSIDE & $\begin{array}{l}\text { SIDING, DOCK } \\
\text { OR R. R. CAR }\end{array}$ & $\begin{array}{l}\text { MILl or } \\
\text { PLANT }\end{array}$ & CONSUMER \\
\hline- & \multirow{11}{*}{$\begin{array}{c}\$ \\
3.25 \\
\ldots \ldots . \\
3.85 * \\
\ldots \ldots . \\
\ldots \ldots . \\
39.86 \\
33.33 \\
2.98 \\
\ldots \ldots . \\
\ldots \ldots . .\end{array}$} & \multirow{11}{*}{$\begin{array}{c}\$ \\
8.80 \\
63.04 \\
7.50 \\
4.49 \\
\cdots \ldots . \\
\cdots \ldots . . \\
25.00^{*} \\
18.18^{*} \\
8.57 \\
7.40^{*}\end{array}$} & \multirow{11}{*}{$\begin{array}{r}\$ \\
\ldots \ldots . \\
\ldots \ldots . \\
15.00 \\
\ldots \ldots . \\
29.38 \\
\ldots \ldots . \\
\ldots \ldots . \\
\ldots \ldots . . \\
\ldots \ldots . \\
\ldots \ldots . .\end{array}$} & \multirow{11}{*}{$\begin{array}{c}\$ \\
19.87 \\
\ldots \ldots \\
17.98 \\
8.33^{*} \\
24.99 \\
116.67 * \\
\ldots \ldots . \\
\ldots \ldots . \\
\ldots \ldots . \\
\ldots \ldots .\end{array}$} & $\$$ \\
\hline Sawlogs & & & & & 22.50 \\
\hline Posts ............ & & & & & 67.48 \\
\hline Pulpwood & & & & & ...... \\
\hline Mine Props ...... & & & & & 6.61 \\
\hline Ties & & & & & ....... \\
\hline Cooperage ........................ & & & & & ...... \\
\hline Veneer logs ....................... & & & & & -...... \\
\hline Mine timbers ................... & & & & & $15.24 *$ \\
\hline Fuelwood & & & & & $7.14^{*}$ \\
\hline Poles ......... & & & & & ...... \\
\hline All products ........ & 3.17 & 8.18 & 24.03 & 27.19 & 13.59 \\
\hline
\end{tabular}

* Data from one sale only. 
The second column in Table 5 was included to show the relation ship between unit value and sales volume of the product classes. Ihe most significant outcome of this comparison is the latet that thene prosduct classes with the lowest unit values-sawlogs, minc props, and mine timbers-made 41 ) 89 per rent of the total solume ol all products manketed.

\section{VALUE BY POINT OF SALE}

The value data on sawlogs, posts, pulpwood, and mine props at the various points of sale indicate an earned increnent for the addicional labor and equipment required as the point of sale becomen funther removed from the stump) (Table 6). For the remaining products, except ing raitroad ties, trends cannot be identilied because in carch product class reliable data occur for one point of sale only.

In the casc of railroad ties, sales made at a siding, dock, or railroat car suggest that the product has been processed, presumably handhewn ties, whereas the delivery to a mill or plant implies that the product will be processed into ties at that point of sale. It is prossible, therefore, that the higher value of ties at the siding, dock, or rational carl means simply that more labor and equipment are required in the processing and delivery of ties than to deliver the rough product to whit nomally would be a more distant point of sale.

The data in Table 6 for "all products" averages slow thal produce value increases at cach point of sille from stmmp to the mill or plant and then drops off at the consumer level. This drop stems from the fact that mine props, a low-value product at any point of sale, (onmprised hit) per cent of the total volume of all products makcted to comsumers. The "all products" value at the consumer point of sille, being a weightuel average, is thus influenced by the matkeng of a relativel! latge wolume of a low-value product.

\section{VALUE BY SPLCIIS}

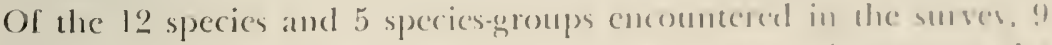

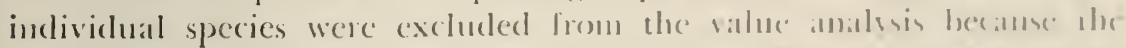

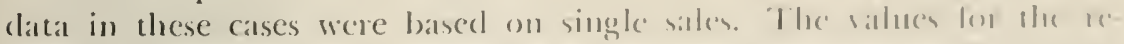

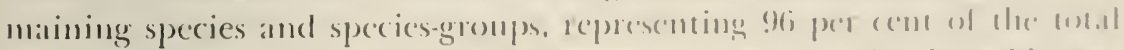

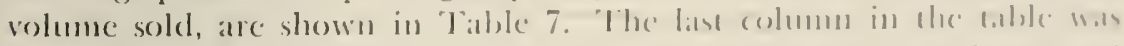
adeled to show the relationship between yperies balue and type at

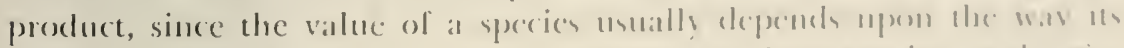
volume is distributed into various produet mulets: yperies usal prin

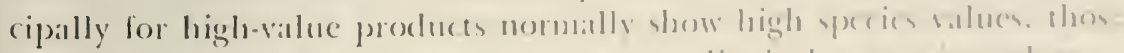

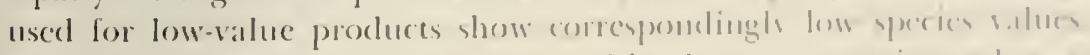

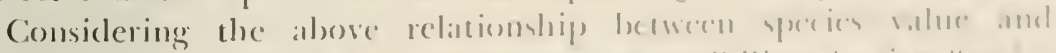

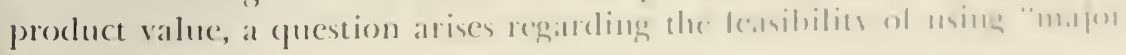


Iabli: 7. Species Marketen in West Virginia-by Value and Major Pronuct Outlet, $1947-51$

\begin{tabular}{|c|c|c|}
\hline SPECIES & $\begin{array}{c}\text { Dollars Per } 100 \text { Ctbic Feet } \\
\text { of Yoltile Marketed }\end{array}$ & $\begin{array}{c}\text { MAJOR PRODUCT } \\
\text { OUTLET }\end{array}$ \\
\hline White oak ................. & 81.22 & Tight cooperage \\
\hline Black locust & 49.31 & Posts \\
\hline Black walnut .......... & 26.14 & Veneer logs \\
\hline 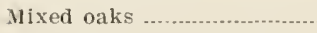 & 16.64 & Sawlogs, Ties, Pulpwood \\
\hline Pine spp. & 16.29 & Pulpwood \\
\hline Mixed hardwood-softwood & 7.65 & Sawlogs, Pulpwood \\
\hline 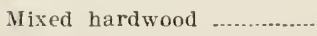 & $7.2 S$ & Sawlogs, Mine props \\
\hline Northern hardwoods ......... & 3.13 & $\begin{array}{l}\text { Mine timbers, Sawlogs \& } \\
\text { Mine props }\end{array}$ \\
\hline
\end{tabular}

product outlet" rather than a classification of species values by individual types of products. By the latter method, the value of any given species could be shown for each type of product as, for example, the value of white oak sawlogs, white oak cooperage, and white oak ties. Such a classification, although it would provide for the most effective analysis of species value, was not possible with the data at hand because the process of dividing and subdividing the number of sales for any given species resulted in too many single-sale values.

A distinct correspondence exists between product value and species value for the extremes in the array of values in Table 7 . For example, the high value for white oak results from the fact that 71 per cent of the white oak volume marketed went into tight cooperage, the highest value product (Table 5). Black locust ranks second highest in species value, with 75 per cent of its volume maiketed for posts, the second highest in product value. Most of the black walnut, ranking third in species value, went into veneer logs, which rank third in product value. At the other end of the scale, the low comparative value of northern hardwoods is related to the fact that all of the volume of this speciesgroup was marketed for sawlogs, mine props, and mine timbers. As indicated in Table 5, these three products represent the least remunerative outlets.

Between the above extremes, the value rank of species depends upon the proportions of total volume going into various products. Thus, mixed oak ranks somewhat higher in value than mixed hardwoodsoftwood because 54 per cent of the mixed oak volume was sold for tics and pulpwood, whereas 54 per cent of the mixed hardwood-softrood volume was marketed for sawlogs. As shown in Table 5 , the value of ties and pulpwood considerably exceeded that of sawlogs.

The loregoing discussion is not indicative of the degree of marketing efficiency existing in the study areat. There is no way of knowing the volume of cooperage-quality white oak that was sold for sawlogs, 
the volume of tie-quality oak that was solel for minc timbers, lhe rolume of veneer-quality black walnut that was marketed for sawlogy, and s) (on. However, the data presented in Table 7 do indicate, to some degrec, the monetary returns which attend eflicicnt marketing.

The above may be excmplified by comsidering the sale of highquality white oak for tight cooperage. The most complete milistion of the technical properties of high-quality white mak would be obtanded in the tight cooperage matket because white oak is practically the only type of wood which measures up to the various spceifications reguired in the manufacture, and in the ultimate use, of this particular wool product. Therefore, efficient marketing of high-equality white rak woulel be achieved by channeling this species into the tight cosperage matiket. If sellers were to so market their white ork timber, thes wombl, theoretically, receive a highes return than that obtainalse from an! of the other market outlets. This is indicated by the data in Table 7 which show that the value of white oak exceeled that of all other specios and. significantly, that most of this white oak was matketed lor tight (o) age. The sale of cooperage-quality white oak in other minket sutlets. such as sawlogs, mine props, or mince timbers, would represent a decrease in marketing efficiency and would be accompanicel by a reduction in the value received for the species. Table 7 rellects this, indirectls, in the lower values shown for those species sold in the sirwlug. mine props. and/or mine timber markets. Although no values alle given for white oak in these markets, there is no logical reason lor ammoling thall the

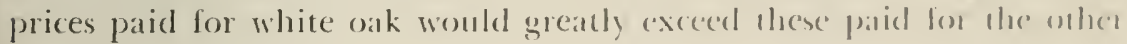
species.

If the analytical procedure used in the abose (ximple were we be

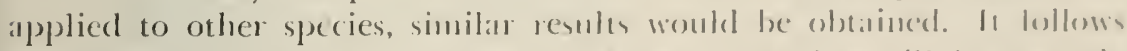
from this that efficiency in lorest problucts mathening will le wough

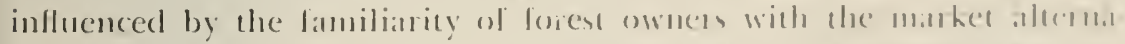
tives available to them, and with the guality of the limber thes plan (o) market.

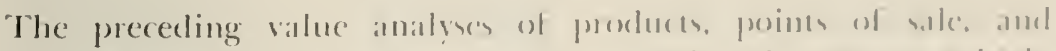

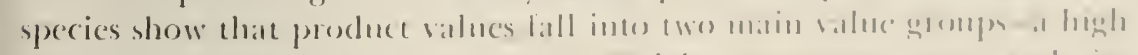

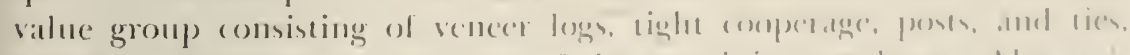

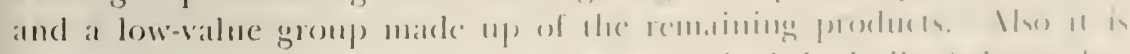

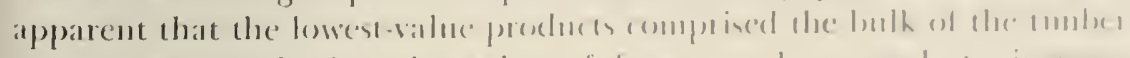

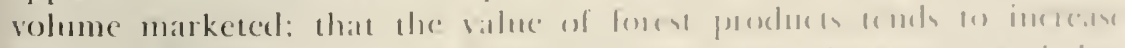

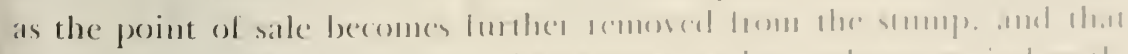

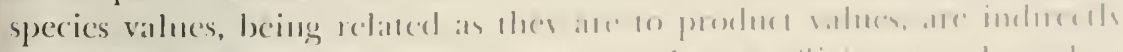

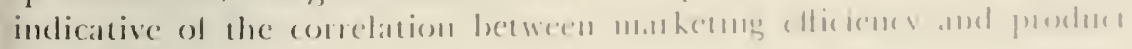
value. 


\section{Marketing Practices}

One significant result arising from the fundings discussed in Sections $V$ and VI has to do with the low value of the three products which comprised most of the volume marketed in the study area. For an explanation as to why the most important products in terms of volume were the least important in terms of value, it is necessary to examine at rather wide range of associated factors. The most logical approach in this case would be to start with the specific marketing practices that characterize the area studied because these practices are mainly responsible for the existence of the situation. Forest products marketing practices, in this study, reler to methods of sale, methods of product measurenent, and methods of product grading.

\section{METHODS OF SALE}

Since product value is determined primarily by the prices paid for products, the methods of price determination would have much to do with the prices paid in the timber products market, and with the value received by timber owners from sale of their products. In this survey, price was determined by the offer of one buyer on almost three-fourths of all the sales reported (Figure 5). The results also imply that sellers were not interested in securing competitive bicls. One likely cause for this is that the woodland owners probably did not know where to contact potential buyers. Further, as was pointed out in Section IV, the majority of sales were made on small woodlot ownerships. Therefore, the total quantity of timber avitilatse for sale on most of these

\begin{tabular}{|l|l|}
\hline OFFER OF ONE BUYER & $70.7 \%$ \\
\cline { 2 - 2 } & \\
ASKING PRICE OF SELLER & $14.9 \%$ \\
COMPROMISE PRICING & $9.0 \%$ \\
BID SOLICITATION & $0.9 \%$ \\
OTHER & $4.5 \%$ \\
\hline
\end{tabular}

FIGURE 5. Percentage distribution of sales by method of price determination. 
woodlots would be rather limited and, as such, offer little in the was of attraction to potential buyers. From this is secmus poublule that to obtain competitive bids might have required nuste time and chlont than most of these woodland owners, all of whom were latmers, wombl catle to expend on an operation which, to them, plays al minom role in the management of their total cuterprisc.

In adclition to accepting the price oller of at single buycr, the majority of the sellers also assented to buyers requirements with respect to various forms of measmement employed in cotablinlsing a basis for payment. As shown in Table 8, buyers estiblished the basis for patyment on 79 per cent of all sales reported. One likely explituation for this is that the sellers in this study atre all engaged in agriculturat pros. duction of one form or another and are generally accustomed to accepting buyers' measurement. Also, with the possible cxception of fucl. wood and fence posts, farmers are usually unfamilar with the terhniques employed in determining timber volumse and therelose must rely on buyers of forest products for estimates or measurement of rolume.

Table 8. Distribltion of Sales by Bash of Payma iN What V'ikgixia. $1947-51$

\begin{tabular}{|c|c|}
\hline BAsis & $\begin{array}{l}\text { J'KH CHext WH ALL } \\
\text { SALKS }\end{array}$ \\
\hline \multicolumn{2}{|l|}{ Buyer } \\
\hline \multicolumn{2}{|l|}{ Jump sum } \\
\hline \multicolumn{2}{|l|}{ lieasurement or count-delivered } \\
\hline \multicolumn{2}{|l|}{ Measurement or count-roadside. } \\
\hline \multicolumn{2}{|l|}{ Measurement or count-in woods } \\
\hline \multicolumn{2}{|l|}{ Measurement at mill-after manufaclure } \\
\hline \multicolumn{2}{|l|}{ Specified estimate of volume-standing timber } \\
\hline \multicolumn{2}{|l|}{ Specified quantily of timber to be cut ............ } \\
\hline \multicolumn{2}{|l|}{ 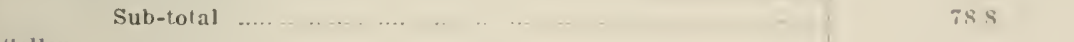 } \\
\hline \multicolumn{2}{|c|}{ 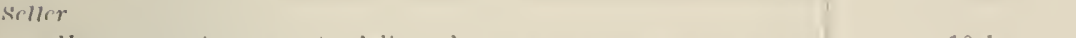 } \\
\hline \multicolumn{2}{|c|}{ Measurement or count-delivered _....._- } \\
\hline Heasurement or rounl-roadside & 4.1 \\
\hline \multicolumn{2}{|c|}{ Measurement or count-in woods. } \\
\hline \multicolumn{2}{|l|}{ Sub-total } \\
\hline \multirow[t]{2}{*}{ rolher } & 1.3 \\
\hline & 111111 \\
\hline
\end{tabular}

Athough buyers established probluct price and basis of palument on

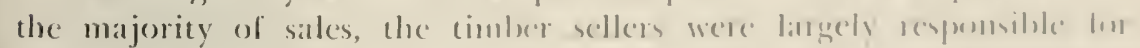

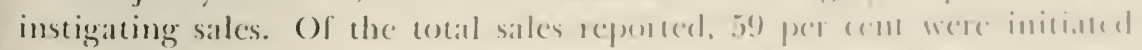

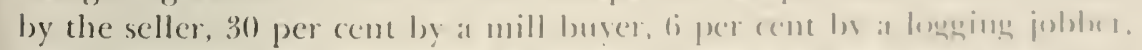

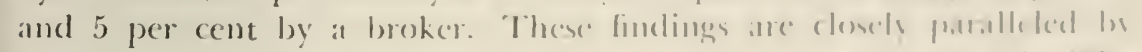

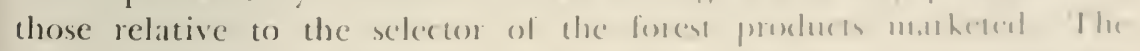

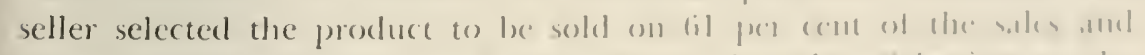

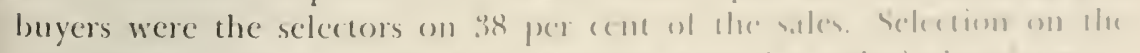

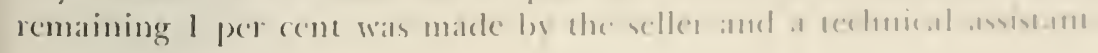


In view of the fact that it was mainly the sellers who initiated the sales and selected the products to be marketed, it is interesting to note the number of sales in which sellers were ruled by noneconomic motives in their selection of a buyer for their timber products. As shown in Table 9, noneconomic reasons were given as the determinants in buyer selection in 13.4 per cent of the sales. By comparison, economic motives governed the selection of buyers on 43.9 per cent of the sales.

Table 9. Reasons for Buyer Selection, IVest Virginia, 1947-5l

\begin{tabular}{|c|c|}
\hline REASON & $\begin{array}{c}\text { Per Cent of AlL } \\
\text { SAles }\end{array}$ \\
\hline \multicolumn{2}{|l|}{$\overline{\text { Eronomic }}$} \\
\hline 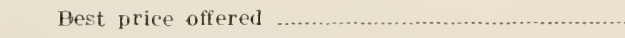 & 19.0 \\
\hline Buyer's location best for delivery. & 14.5 \\
\hline 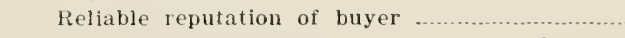 & 5.4 \\
\hline Buyer would purchase less valuable products .. & 1.8 \\
\hline Buyer would purchase marked products ............ & 1.4 \\
\hline 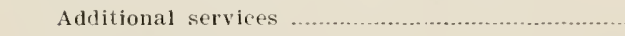 & 0.4 \\
\hline Buyer would purchase a variety of products ...... & 1.4 \\
\hline Sub-total & 43.9 \\
\hline \multicolumn{2}{|l|}{ Nonceonomic } \\
\hline 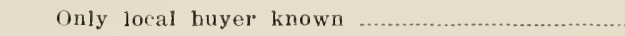 & 21.7 \\
\hline Friendship & 11.8 \\
\hline 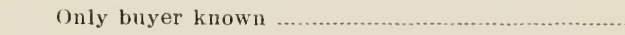 & 6.3 \\
\hline Long-standing business counection with buyer & 3.6 \\
\hline Sub-total & 43.4 \\
\hline \multirow[t]{2}{*}{ other } & 12.7 \\
\hline & 100.0 \\
\hline
\end{tabular}

From the foregoing discussion of methods of sale, it would seem that the low unit value of the three major products might, in part, be attributed to a depressed price level caused by imperfections in the forest products market of the area. Certainly the control which buyers are in position to exert indicates the strength of their bargaining position and, as a consequence, the weakness in the bargaining position of the sellers.

\section{METHODS OF PRODUCT MEASUREMENT}

With the buyers establishing the basis of payment on most sales, it might be expected that measurement of products would be handled largely by them. This was the case. Buyers did the measuring on more than two-thirds of all sales, sellers measured products on 13 per cent, and on 15 per cent of the sales no product measurement was made.

For sales involving product measmement, two mits of measure, hoard foot and piece tally, accounted for 92 per cent of the total volume marketed (Table 10). Slightly more than two-thirds of the volume sold was measured on a board-foot basis, most of which was based either on the Iryle $\log$ rule or on some rule unknown to the seller. A little more 
rule indicates; lourteen-inch logs, 30 to 35 per cent more; and cight-inch logs, more than 150 per cent more.":"

Although no data were obtained in this survey on the log sizes marketed, it would not be unrealistic to presume that small-size logs made up the bulk of the sawlog volume sold. Also, considering the common use of the Doyle rule by private dealers in the Appalachian region, it would be reasonable to assume that this rule predominated on those sales classified under "M bd. ft., uncualified." If these assmmptions are valid, then, for the major share of the product volume marketed, the measurement practices cmployed have clearly operated to the disadvantage of timber sellers.

\section{METHODS OF PRODUCT GRADING}

Buyer control is apparent in timber products grading to an even greater extent than in product measurement. The data secured in this study show that buyers did the grading on 42 per cent of all sales reported, sellers graded on 4 per cent, and on the remaining 54 per cent products were not graded. As might be expected with buyers doing most of the grading, the grading systems employed were mainly those developed by buyers. Buyers' grades were used on nine-tenths of all sales involving product grading; on the other one-tenth, standard grades were followed.

In review of the foregoing description of marketing practices, onc point stands out significantly: that methods of sales, of product measurement, and of product grading usually operate in favor of the buyer. This constitutes a likely explanation for the low unit value of the principal products marketed by sellers in the area. Since the values for these products, as shown in the Section on value of products marketed, are weighted averages, they necessarily incorporate the effects of volume as well as price. Therefore, a combination of low product price and inequitable measurement techniques, coupled with the fact that stmmpage sales accomnted for more than one-half of the volume sold, implies that low product value will result.

\section{Familiarity of Sellers with Timber Products and with the Timber Products Market}

It would appear from the findings discussed thus far that farm roodland owners have marketed the bulk of their timber volume in ways which would be least advantageous to them. Since these farmers would not nomally employ similar practices in marketing their dairy

"Duerr. W. A., Eronomir Problems of Forestry th the Appuluchiun Reyion, Cambridge: Harvard iniversity Press, 1949, p. 190. 
Considering "other sources," sellers most frequently mentioned a buyer of one solt or another, such as a timber broker, a logging jobber, or a sawmill buyer. It is not to be expected that these sources would be inchined to inform potential sellers of other, and possibly more remunerative, outlets for their timber products.

In addition to their mnfamiliarity with markets for their products, sellers also lack knowledge relative to available marketing assistance. On approximately two-thirds of the sales, sellers stated that they had possessed no presale information regarding agencies or individuals who provide assistance in the marketing of forest products (Table 12). For those sales in which sellers reported that they were aware of available marketing assistance, the source most frequently mentioned was the larm or county forester.

Table 12. Distribution of Sales in West Virginia-by Presale Knowledge of Available Marketing Assistance, 1947-51

\begin{tabular}{|c|c|}
\hline Source of Assistance & $\begin{array}{c}\text { Per Cent of ALL } \\
\text { SALES }\end{array}$ \\
\hline Farm or county forester & 22.1 \\
\hline State forest service ................................ & 7.1 \\
\hline 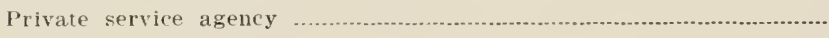 & 2.5 \\
\hline Other & 4.6 \\
\hline Presale knowledge of available assistance ................. & 36.3 \\
\hline No presale knowledge of available assistance. & 63.7 \\
\hline
\end{tabular}

Sellers were also questioned as to their familiarity with the managennent and marketing assistance provided by certain industries, particularly those manufacturing specialized products sucli as veneer and tight cooperage.

The results obtained show that 58 per cent of the sales were made with $n o$ presale knowledge of this type of assistance.

From the foregoing analyses it is apparent that most of the farm woolland owners are largely uninformed regarding timber products and markets for these products. These handicaps, in combination with the lact that timber sales play an incidental, and minor, role in the farm enterprise appear to constitute the underlying reasons for the marketing practices described in Section VII which, in turn, were responsible for the low unit value of the principal products marketed.

\section{Home Use of Forest Products}

Alhough this study was concerned primarily with timber marketing practices, the importance of home use of forest products was also investigated. The results obtained, in terms of volume and value of Iorcst products harrested for home use, and the number of owners using 
their woodlots for this purpose, imply that woodlands are possibly of more significance to owners as is source of necded raw materials than as a source of money income.

\section{FREQUENCY OF CUTTINGS FOR HOME USE}

Fifty-four per cent of the respondents reported that they had cut timber products for direct use on the farm. By way of contrant, 206 per cent of all respondents, less than one-half of the proportion cutting for home use, reported sales of woodland products.

The data in Table 13 show that the bulk of the cutting was done to get needed products for homestead maintenance and repair and, as with sales of timber products, that most of the activily took place in the smallest woodland area size classes.

Table 13. Number of Cutrings for Home. Use by Reason for CuTtTixo

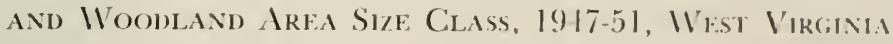

\begin{tabular}{|c|c|c|c|c|c|}
\hline \multirow{2}{*}{$\begin{array}{c}\text { WOODLAND AREA } \\
\text { SIZE CLASS } \\
\text { (ACRES) }\end{array}$} & \multicolumn{3}{|c|}{ REAson for Cuttixg } & \multicolumn{2}{|r|}{ TutAl. } \\
\hline & $\begin{array}{l}\text { MAINTENANCE } \\
\text { AND REPAIR }\end{array}$ & $\begin{array}{l}\text { HOMESTEAD } \\
\text { IMPROVEMENTS }\end{array}$ & ОTHEI & A1.L & $\begin{array}{l}\text { PliR C'NAT GW AI.L } \\
\text { CITTINis }\end{array}$ \\
\hline $10-49$ & $\begin{array}{l}\text { No. } \\
169\end{array}$ & $\begin{array}{l}\text { No. } \\
35\end{array}$ & $\begin{array}{c}\text { No. } \\
3\end{array}$ & $\begin{array}{l}\text { No. } \\
\text { 2(1i }\end{array}$ & 5.5 .2 \\
\hline $50-99$ & 66 & 24 & 3 & 93 & 24.5 \\
\hline $100-199$ & 43 & 8 & 1 & 52 & 13.9 \\
\hline $200+\ldots \ldots$ & 16 & 7 & 0 & $2: 3$ & 0.1 \\
\hline Total & 294 & 74 & 7 & 375 & 1011,11 \\
\hline $\begin{array}{l}\text { Per cent of all } \\
\text { cuttings ......... }\end{array}$ & 78.4 & 19.7 & 1.9 & 100.0 & c \\
\hline
\end{tabular}

VOLUME OF PRODUCTS CUT FOR HONE ISE

In order to make volume complatisoms of products cut for home use, all reported volume data were converted into rubie-foot equivalents. Is indicated in Table 14, fuelwood, sawlogs and posts comprised the prin(ipal products havested for direct use, with fuclwood alome alcomming for more than one-half of the total ammul cut.

Considering volume of cut by weolland areal dasse the "all pun ducts" totals show a decrease in volume remowed with incencese in womel

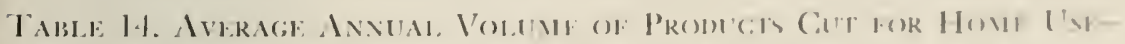

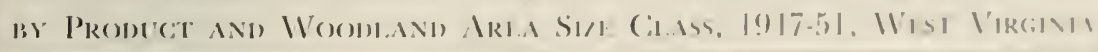

\begin{tabular}{|c|c|c|c|c|c|c|c|}
\hline \multirow{2}{*}{ 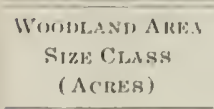 } & \multicolumn{5}{|c|}{ 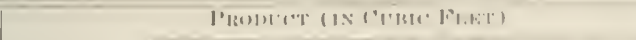 } & \multicolumn{2}{|c|}{ 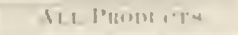 } \\
\hline & FrVLWU) & SAWLUIS & Wrista & $\begin{array}{l}\text { MINk } \\
\text { I'muPB }\end{array}$ & InI. A & $\begin{array}{l}1 \times 111 \\
1 \because 11\end{array}$ & 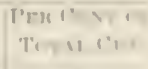 \\
\hline $3(1-4 !)$ & $74.7 \sin$ & $11,6(11)$ & $1,, 4111$ & 5,77 & $11: 5,11$ & $1,1,4$ & $1: 1$ \\
\hline $5(1-9 ! 91-\ldots \ldots \ldots$ & $18.11911)$ & $5: 3,570$ & 3.1185 & 5,522 & 1,211 & $111142 \%$ & ! - \\
\hline 1601-199 ....... & $20,46,11$ & 5,9811 & $1,4: 1.1$ & 11 & 507 & 11574 & 111 \\
\hline $2(n)+\ldots \ldots$. & 21,1120 & 1,735 & 1.571 & 11 & $" 1$ & 26. 210 & it \\
\hline All classes & I(i)1,2:31) & 105,175 & $1: 3.1:: 3$ & $1 ;, 11 ! 3+1$ & $\because 7 \div$ & 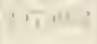 & che $n$ \\
\hline $\begin{array}{l}\text { Per cent of } \\
\text { lolal cut ... }\end{array}$ & 51,9 & :15.6; & 1.5 & 2.1 & (1)! & $(1+10)$ & \\
\hline
\end{tabular}


land area size class. Almost four-fifths of the total ammal cut for all products came from woollands averaging less than 100 acres in area.

An annual volume of 297,662 cubic feet of wood cut for home use (Table 14) represents 70 per cent of the total volume of all timber products harvested annually for the five-year period considered in this study. Therefore, with only 30 per cent of the total ammal cut going into the forest products market, woodlands in this study area cammot be meastured sclely in terms of the volume of wood sold.

\section{VALUE OF TIMBER PRODUCTS CUT FOR HOME USE}

In determining values for products used directly, the best approach would be to use values obtained from sales of these products. For example, if a farmer cuts posts for fence repair, the value of the posts may be considered as the equivalent of what the farmer would have received had he sold them, or what he would have had to pay to buy them. The same principle holds for fuelwood, mine props, and poles. Detemining values for these four products, in this study, was facilitated by the fact that roadside sales accounted for 100 per cent of the pole volume sold, 85 per cent of the mine prop volume, 90 per cent of the post volume, and 88 per cent of the fuelwood volume. Therefore, the lollowing values, which represent the average amount received per 100 cubic feet of product marketed at this one point of sale, were used to determine the total value of luelwood, posts, mine props, and poles cut lor home use:

$$
\begin{aligned}
& \text { Fuelwood } \ldots \ldots \ldots \ldots \ldots \ldots \ldots . \$ 8.57 \text { per } 100 \text { cubic feet } \\
& \text { Posts } \ldots \ldots \ldots \ldots \ldots \ldots \ldots . \$ 63.04 \text { per } 100 \text { cubic feet } \\
& \text { Mine props } \ldots \ldots \ldots \ldots \ldots \ldots . \$ 4.49 \text { per } 100 \text { cubic leet } \\
& \text { Poles } \ldots \ldots \ldots \ldots \ldots \ldots \ldots \ldots . \$ 7.40 \text { per } 100 \text { cubic feet }
\end{aligned}
$$

The value of sawlogs cut for home use cannot be determined by the above method. As has been noted earlier (page 14), most of the sawlog volume was marketed on the stump. However, the average return per 100 feet of sawlogs marketed at this point of sale cannot be used as a value indicator because it does not reflect the value added by harvesting, tramsporting, and processing the raw material into a useable product. Therefore, the imputed value for sawlogs was arrived at on the basis of the average returu secured from reported sales of sawlogs delivered to the mill or plant. This figure was increased by an estimated average milling cost of \$16 per thousand board leet for sawing mill-run lumber. This, converted to a cubic-foot basis, resulted in a value of $\$ 29.01$ for every 100 cubic leet of sawlogs cut for home use-an estimate very likely on the conservative side because: (a) transportation cost of the lumber from mill to place of use has not been included, and (b) all available 
mentary enterprise and, with an average area of 50 acres, a very minor one since small woodlands involve a scale of operations not sufficiently large to encourage the adoption of the most efficient methods of management by the individual. Moreover, because of the existence of certain remnants of pioncering agricultural tradition, the timber resource, by and large, is not even recognized as a crop. As a consequence, farm woodland owners generally are reluctant to spend much of their time and effort in management of their woodlands, in developing specific skills required for harvesting, measuring, and grading timber products, or in becoming acquainted with all of the marketing information necessary for efficient marketing of woodland products. The logical accompaniment to ail this is low timber product value which tends to further aggravate the minor position of the timber products enterprise. Accordingly, increasingly less attention is given to management of the farm woodlands and, in turn, the position of farm woodland owners in the timber products market becomes still more unfavorable. In contrast, the major interests of timber buying centers on the production and marketing of wood products. Conscquently, the buyer usually has a much clearer idea of product outlets and product values than does the seller.

It is evident from the foregoing that an eventual realization of the long rum objective of "good" management on small, privately owned woodlands will depend upon the development of a more equitable marketing situation than that which now exists. If present conditions are continued, the timber seller's share of the consumer's dollar will remain relatively low, and little can be expected in the way of more conservative managenent on woodlands in farm ownership. Certain recommendations such as product integration, bid solicitation, familiarization with market outlets, with measurement and grading of timber products, and with marketing services, could be made here which, if followed, should improve the market position of farm woodland owners. But such recommendations have often been made in the past without effecting any noticcable change in timber marketing practices. It secms that recommendations made from the standpoint of technical forestry are not compatible with practicality from the famers' point of view at the present time. Also, adoption of such practices might entail much more tine and cllort than most larmers would care to give to the forestry part of their fam enterprise, which plays a minor role in their economy.

The basic problem evolving from the above discussion is one of deternining how to initiate the adoption and application by small woodland owners of practices requisite to the development of a more equitable marketing system. There are two parts to this problem: one has to do with the matter of providing timber sellers with adequate informa- 
hence, in part, the degree to which it maximizes its net returns-is basically dependent upon the amount of knowledge possessed by the firm regarding all possible alternatives. By applying this principle to sellers in the timber products market, it becomes obvious that efficient marketing is, first of all, governed by the seller's awareness of existing outlets for his timber products-the more limited the potential seller's knowledge, the less the probability that each tree or $\log$ will be directed into that use for which it is best suited.

Aclditional research could also be performed in the field of price reporting. This would involve investigation of the methods by which dependable price data could be regularly obtained and most effectively transmitted to market participants. Included here also, of course, would be information on product specifications.

Finally, studies on the structure and organization of the forest products markets in West Virginia would also be of value. Information obtainable from investigation in this subject field is fundamental to a more effective appraisal of the efficiency of the marketing system and to a more specific identification and definition of the problems arising as wood products are moved from producer to consumer. In the final analysis, problems of the producer are not based entirely on causes at the producer end of the marketing chain; problems occurring throughout the entire marketing mechanism necessarily exert some influence down the line toward the producer-hence, research on market structure may be as much related to the producer as to any other functionary in the marketing chain.

\section{Summary}

This study of the marketing practices and customs of private woodland owners in West Virginia is based on a field survey of ownership units containing woodlands ranging in size from 10 to 500 acres. For cach ownership unit, data were obtained during the summer of 1952 on woodland area and composition, on sales of products, and on products used directly by owners for a five-year period, 1947 through 1951.

WOOIILAND OWNERSHIP

Nearly one-half of the total area in the sample is covered by forest land comprised mainly of many smatl larm holdings. Most of this moodland area is occupicd by hardwood cover types, with sawtimber stands covering approximately one-hall of the total woodland acreage.

\section{S.LLES OF THMBER PRODUCTS}

The majority of the timber products sales, motivated largely by owners' needs for money or for open land, are made by owners in the 
smallest woodland area classes. Most of these owners mathet only one type of product in any given transaction.

The principal products marketed, on a volume basis, are salwlogs and mine props. These products are derived mainly from the northern hardwoods and mixed hardwoods species-group and are sold cloue to their point of origin, stumpage sales accounting for must of the sawlog volume marketed, and roadside sales representing the major portion of the mine prop volume sold.

In terms of unit value, using 100 cubic feet as the unit, two productgroups appear: a high-value group consisting of vencer logs, tight cooperage, post, and ties, and low-value group composed of sawloge, mine props, mine timbers, plupwood, and poles. The low-value products make up the bulk, 94 per cent, of the timber volume marketed. This high proportion of low-value products is reflected in the modest return to those making sales of $\$ 1.99$ per acre per year from the salc of forest products.

\section{MARKET POSITION OF SELLERS}

The marketing practices employed, methods of sale, of product measurement, and of product grading, secm to favor the buyer of timber products predominantly. This creates an unfavorable market position on the part of the timber products sellers. This situation mal be partially explained by seller unlaniliarity with cimber produces and with the markets for these products.

\section{HOME USE OF FOREST PRODUCTS}

Farm woodlands appear to be of primary importance as a source of raw materials for direct use on the farms. Home use of forcst products accounts for 70 per cent of the total volume, and 85 per cent of the total value, of all forest products harvested ammually for the fire-pean period investigated. 
